\title{
Additional Surgery for New Loco-Regional Tumor Event Was Not Performed
}

National Cancer Institute

\section{Source}

National Cancer Institute. Additional Surgery for New Loco-Regional Tumor Event Was

Not Performed. NCI Thesaurus. Code C160445.

Additional surgery was not performed for a new loco-regional tumor event. 